6 Esteban JI, Esteban R, Viladomiu L, et al. Hepatitis C virus antibodies among risk groups in Spain Lancet 1989;ii:294-6, 297.

Van der Poel CL, Reesink HW, Lelie PN, et al. Anti-hepatitis $C$ antibodies and non-A, non-B posttransfusion hepatitis in The Netherlands. Lancet 1989;ii:297-8.

8 Kuhnl P, Seidl S, Strangel W, Beyer J, Sibrowski W, Flik J. Antibody to hepatitis C virus in German blood donors. Lancet 1989;ii:324.

Roggendorf M, Deinhardt F, Rasshofer R, et al. Antibodies to hepatitis C virus. Lancet 1989;ii: $324-5$ 10 Arima T, Shimomura H, Tsuji T, et al. Serum RNA associated with blood-transmitted non-A,
non-B hepatitis. Hepatology 1988;8:1275.

11 Bradley DW, McAusterland KA, Cook EH, Schable CA, Ebert JW, Maynard JE. Post-transfusion non- $\mathrm{A}$, non- $\mathrm{B}$ hepatitis in chimpanzees. Physicochemical evidence that the tubule-forming agent is a small, enveloped virus. Gastroenterology 1985;88:773-9.

12 He L-F, Alling D, Popkin T, Shapiro M, Alter HJ, Purcell RH. Determining the size of non-A, non-B hepatitis virus by filtration. $\mathcal{F}$ Infect Dis 1987;156:636-40.

13 Fagan EA, Ellis DS, Tovey GM, et al. Virus-like particles in liver in sporadic non-A, non-B fulminant hepatitis. I Med Virol 1989;27:76-80.

14 Fagan EA, Ellis DS, Tovey GM, et al. Toga-like virus as a cause of fulminant hepatitis attributed to sporadic non-A, non-B hepatitis. $\mathcal{F}$ Med Virol 1989;28:150-5.

15 Contreras M, Barbara JAJ. Screening for hepatitis C antibody. Lancet 1989;ii:505.

16 Bradley DW. The agents of non-A, non-B hepatitis. $\mathcal{F}$ Virol Methods 1985;10:307-19.

17 Zuckerman AJ. The three types of human viral hepatitis. Bull WHO 1978;56:1-20.

\title{
Peripheral vascular disease
}

\section{Physical treatments may help}

Intermittent claudication is usually caused by an arteriosclerotic stenosis that limits blood flow to the legs so that the increased demand during muscular work cannot be met. In the more advanced stages of occlusive peripheral vascular disease perfusion may no longer be adequate even at rest, and rest pain and eventually gangrene may result. Ideally the affected arteries should be reopened by surgery or fibrinolytic treatment. These methods are not, however, indicated in patients with the less severe forms of peripheral vascular disease; they are not possible in some patients and are unsuccessful in others. ${ }^{1}$ In such cases the alternative treatments include drugs and haemodilution, both of which may alleviate symptoms. ${ }^{2}$ A third possibility is physical treatment, which has the advantage of having fewer side effects.

Exercise is undoubtedly the most effective conservative treatment for patients with intermittent claudication. Controlled trials have shown that it doubles or even trebles the distance that can be walked before pain occurs. ${ }^{3+}$ Supervised long term treatment has a response rate of around $80 \%$. $^{5}$ Specific forms of exercise are sometimes helpful. They offer the advantage of "individualising" the treatment: depending on the site of the stenosis, the patient may (selectively) train those muscles that suffer the worst hypoxia. ${ }^{6}$

Most vascular surgeons advocate exercise only for patients with intermittent claudication, yet at least two studies have shown benefit for patients with rest pain..$^{78}$ Various mechanisms seem to play a part in improving symptoms: haemodynamic changes help to redistribute the blood flow, metabolic alterations within the muscle cell optimise oxygen utilisation, and structural changes in the musculature affect both microvessels and muscle fibres. Other factors may be changes in walking technique, psychological responses, and improved rheological features in the blood. ${ }^{9}$

Various electrical treatments have been tried to extend the walking distance in patients with claudication. ${ }^{10}$ One trial of transcutaneous electrical nerve stimulation reported a $125 \%$ prolongation of the walking distance with stimulation compared with only $41 \%$ in the control group. "The mechanism of this effect could be either an analgesic effect or changes in blood flow. Transcutaneous electrical nerve stimulation has been shown to enhance perfusion of the skin, as shown by the laser Doppler technique, ${ }^{12}$ but whether this also holds true for the musculature is less clear. The analgesic effects are thought to work by the gate control mechanisms and could well contribute to the effectiveness of this treatment in peripheral vascular disease. ${ }^{13}$ Epidural electrostimulation has also been reported to be helpful in patients with vascular disease, but the technique has the disadvantage of being invasive. ${ }^{14} \mathrm{At}$ present the verdict must be that the place of electrical treatments in peripheral vascular disease needs further clinical assessment.

Yet another treatment is immersion of the patients in a bath enriched with carbon dioxide. ${ }^{15}$ This causes hyperaemia of the skin, but this by no means indicates hyperaemia in the musculature beneath. There is also some evidence, however, that carbon dioxide might restore the flow characteristics of the blood towards normal. ${ }^{16}$ Recently we concluded a controlled clinical trial of 800 patients with cardiovascular disease showing that regular carbon dioxide baths lowered blood viscosity (unpublished results). External carbon dioxide also improves blood flow in the microcirculation of the skin. ${ }^{77}$ This treatment has, therefore, a rational basis, but clinical proof of effectiveness is still lacking.

Clearly, physical medicine has a place in treating peripheral vascular disease. Exercise is the most successful and cost effective treatment in patients with intermittent claudication. Other approaches such as electrotherapy and external carbon dioxide may seem worth trying when all else has failed, but they need to be investigated more thoroughly. There are some even more bizarre options - ultrasound, ultraviolet radiation, massage, and intermittent compression; but at present these lack both a rationale and proof of effectiveness. ${ }^{18-20}$

Professor,

E ERNST

Abteilung Physikalische Medizin und Rehabilitation,

Medizinische Hochschule Hannover,

Postfach 6101 80, D-3000 Hanover 61, Federal Republic of Germany

1 Linhart J. Ischaemic disease of the lower extremities: diagnosis and conservative treatment with particular reference to long-term control. Eur Heart $\mathcal{\text { 1987 }}$ 198:1156-69.

Ernst E, Matrai A, Kollar L. Placebo-controlled, double blind study of haemodilution in peripheral arterial disease. Lancet 1987 ;ii: 1449-51.

3 Larsen OA, Lassen NA. Effect of daily muscular exercise in patients with intermittent claudication. Lancet 1966;ii:1093-5.

4 Ernst E, Matrai A. Intermittent claudication, exercise and blood rheology. Circulation 1987;76: 1110-4.

5 Buchwalsky R, Blumchen G, Kurz- und Langzeiteffekte körperlichen Trainings. In: Muller WH, Barras SJP, Ehringer H, Krieger M, eds. Mikrozirkulation und Blutrheologie. Baden Baden:

6 Krause D, Dittmar K. Ergebnisse bei der physikalischen Therapie peripherer arterieller Drause D, Dittmar K. Ergebnisse bei der physikalischen Therapie peripher
Durchblutungsstörungen. Münchner Medizinische Wochenschrif 1974;116:385-9.

7 Foley WT. Treatment of gangrene of the feet and legs by walking. Circulation 1957;15:689.

8 Andriessen MPHM, Barendsen CJ, Wouda AA, de Pater L. The effect of six months' intensive physical training on the circulation in the legs of patients with intermittent claudication. Vasa 1989;18:56-62.

9 Ernst E. Physical exercise for peripheral vascular disease. Vasa 1987;16:227-32

10 Edel H. Fibel der Elektrodiagnostik und Elektrotherapie. Munich: Muller, Steinick, 1983.

11 Bühring M, Sayegh A, Blumenthal E, Klöckner M, Saller R. Elektrotherapie bei Patienten mit Claudokatio intermittens. Zeitschrift für Physikalische Medizin, Balneologie, Medizinische Klimatologie 1984;13:8-9.

12 Lundeberg T, Kjartansson J, Samuelsson U. Effect of electrical nerve stimulation on healing of ischaemic skin flaps. Lancet 1988;ii:712-4.

13 Ottoson D, Lundeberg T. TENS - transcutaneous electrical nerve stimulation. Heidelberg: Springer, 1988.

14 Rodriguez M. Epidural electrical stimulation in vasospastic leg ischaemia. Vascular Surgery (in

press).
15 Komoto $\mathrm{Y}$, Komoto $\mathrm{T}$, Sunakawa $\mathrm{M}$, et al. Dermal and subcutaneous tissue perfussion with $\mathrm{CO}_{2}$ bathing. Zeitschschrift fir Physiotherapie 1986;38:103-12.

16 Ernst E, Roloff $\mathrm{Ch}$, Magyarosy I, Drexel $\mathrm{H}$. Hümorheologische Immediat- und Langzeiteffekte des $\mathrm{CO}_{2}$-Bades bei arterieller Verschlußkrankheit, Stadium II. Zeitschrift fir Physikalische Medisin, Balneologie, Medirinische Klimatologie 1984;13:157-62.

17 Schnizer $\mathrm{W}$, Erdl R, Schöps $\mathrm{P}$, Seichert N. The effects of external $\mathrm{CO}_{2}$ application on human skin microcirculation investigated by laser Doppler flowmetry. In $\boldsymbol{\mathcal { F }}$ Microcirc Clin E⿱艹xp 1985;4: 343-50.

18 Bickford JB, Duff RS. Influence of ultrasonic irradiation on temperature and blood flow in human skeletal muscle. Circ Res 1953;1:534-8.

19 Diehm C, Rechtsteiner HJ. Wer heilt recht? München: Zuckschwerdt, 1987.

20 Rithalia SVS, Gonsalkorale M, Edwards J. Effect of intermittent pneumatic compression on lower limb skin perfusion. Angiology 1989;40:249-54. 